\title{
Long non-coding RNA colon cancer-associated transcript 2 may promote esophageal cancer growth and metastasis by regulating the Wnt signaling pathway
}

\author{
XIUCHUN WANG ${ }^{1 *}$ and XUEMEI WANG ${ }^{2 *}$ \\ ${ }^{1}$ Department of Vascular Intervention, Affiliated Hospital of Weifang Medical University, Weifang, Shandong 261031; \\ ${ }^{2}$ Department of Gastroenterology, Renmin Hospital of Wuhan University, Wuhan, Hubei 430060, P.R. China
}

Received October 9, 2018; Accepted May 22, 2019

DOI: $10.3892 / \mathrm{ol} .2019 .10488$

\begin{abstract}
The aim of this study was to investigate how long non-coding (lnc)RNA colon cancer-associated transcript 2 (CCAT2) regulates the proliferation, invasion and metastasis of esophageal cancer cells via the Wnt signaling pathway. The expression of IncRNA CCAT2 was quantified by reverse transcription-quantitative PCR in four esophageal cancer cell lines (Eca-109, EC9706, KYSE150 and TE-1) and normal human esophageal epithelial cells (HEECs). The effect of silencing CCAT2 (si-CCAT2) and inhibiting Wnt signaling (using the inhibitor FH535) on the proliferation, migration and invasion of Eca-109 cells was measured by MTT, wound-healing and Transwell invasion assays. Flow cytometry was used to evaluate apoptosis in si-CCAT2 Eca-109 cells. The expression of $\beta$-catenin and proliferating cell nuclear antigen (PCNA) proteins was detected by immunohistochemistry. The pro-apoptotic protein Bax, cyclin D1 and Wnt target proteins, including c-Myc and adenomatous polyposis coli (APC), were detected by western blotting. LncRNA CCAT2 was highly expressed in the four esophageal cancer cell lines compared with the HEEC cells. The expression of CCAT2 was significantly decreased in si-CCAT2 Eca-109 cells. Treatment with si-CCAT2 and FH535 alone or in combination significantly inhibited the proliferation, migration and invasion of Eca-109 cells. The treatments also promoted apoptosis, upregulated the expression of Bax and APC proteins, and downregulated $\beta$-catenin, PCNA, cyclin D1 and c-Myc proteins. In summary, lncRNA CCAT2 is upregulated in esophageal cancer cells and
\end{abstract}

Correspondence to: Dr Xiuchun Wang, Department of Vascular Intervention, Affiliated Hospital of Weifang Medical University, 2428 Yuhe Road, Weifang, Shandong 261031, P.R. China

E-mail: xjsiw09@163.com

${ }^{*}$ Contributed equally

Key words: long non-coding RNA colon cancer-associated transcript 2, esophageal cancer, Wnt signaling pathway, proliferation, invasion the knockdown of lncRNA CCAT2 inhibits their proliferation, migration and invasion via the Wnt signaling pathway.

\section{Introduction}

Esophageal cancer, including squamous cell carcinoma and adenocarcinoma, affected half a million people worldwide in 2014 , and causes a fatal outcome in the majority of cases $(1,2)$. The incidence rate of esophageal cancer has increased dramatically over the past 40 years (2). Alcohol consumption and tobacco use are major risk factors (3-5). Untreated gastroesophageal reflux disease usually progresses to Barrett's esophagus, which is 50-100 times more likely to develop into cancer (1). Obesity can also increase the risk of developing esophageal cancer, via low-grade inflammation (2). Due to the lack of serosa in the esophageal wall and extensive lymphatic drainage to intrathorax and intra-abdominal lymph nodes, esophageal cancer can spread rapidly into the neck and thorax (2). Advanced stages of esophageal cancer can also spread hematogenously (2).

Long non-coding (lnc)RNA colon cancer-associated transcript 2 (CCAT2) was first identified as a region within the $8 \mathrm{q} 24$ chromosomal location containing a single nucleotide polymorphism and expressed in microsatellite-stable colorectal cancer. This was subsequently identified as a biomarker for poor prognosis and metastasis in esophageal squamous cell carcinoma (ESCC), gastric cancer, bladder cancer, non-small cell lung cancer (NSCLC), small cell lung cancer (SCLC), glioma, ovarian cancer, breast cancer and others (6-9). A number of studies have explored the effect of lncRNA CCAT2 on cancer, using small interfering (si)RNA to inhibit its expression in various cancer cell lines (such as HuCCT1, CCLP1, DU-145, 22RV1, MDA-MB-231 and $\mathrm{MCF}-7)$ (6-13). The results demonstrated that the silencing of CCAT2 inhibits proliferation and invasion of NSCLC, SCLC, glioma, ovarian cancer, bladder cancer, breast cancer and even tamoxifen-resistant breast cancer cells (14-17). These studies indirectly or directly demonstrated that overexpression of 1ncRNA CCAT2 promotes cell proliferation, migration and invasion, and inhibits cell apoptosis, implying that it exerts a tumor-promoting function in many cancer types (10-17). The more extensive studies 
found that CCAT2 promotes proliferation and metastasis via the Wnt signaling pathway and epithelial-mesenchymal transition (10-13). Moreover, it has been reported to regulate cancer cell metabolism via alternative splicing of glutaminase by selecting the poly(A) site in intron 14 of the precursor mRNA (18).

LncRNA CCAT2 was found to be associated with ESCC by in silico analysis and subsequent clinical studies $(4,19)$. These studies showed that CCAT2 was highly expressed in cancer tissue and was associated with smoking $(4,19)$. Lymph node metastasis, advanced lymph node metastasis and Myc amplification were also associated with high lncRNA CCAT2 expression (19). Furthermore, the expression of this IncRNA was positively correlated with Myc amplification and progression of cancer (19).

To investigate the molecular mechanism of lncRNA CCAT2 function in esophageal cancer, the expression of lncRNA CCAT2 in esophageal cancer cells and its association with proliferation and metastasis were investigated in the present study. The results from the current study may provide a theoretical basis for new treatment options for esophageal cancer.

\section{Materials and methods}

Cell culture. Normal human esophageal epithelial cells (HEEC; cat. no. BNCC337729; BeNa Culture Collection; www.bnbio.com) and human esophageal cancer cell lines KYSE150 (cat. no. BNCC342590; BeNa Culture Collection; www.bnbio.com), Eca-109 (cat. no. BNCC337687), EC9706 (cat. no. BNCC339892) and TE-1 (cat. no. BNCC100151) (all BeNa Culture Collection) were cultured in RPMI-1640 medium (Gibco; Thermo Fisher Scientific, Inc.) containing $10 \%$ FBS (Sigma-Aldrich; Merck KGaA) under conditions of $37^{\circ} \mathrm{C}$ and $5 \% \mathrm{CO}_{2}$ in a cell incubator (Thermo Fisher Scientific, Inc.). Growth phase cells ( $80 \%$ confluence) were used for subsequent experiments.

Grouping. Based on the expression level of lncRNA CCAT2 in the four esophageal cancer cell lines, the Eca-109 cell line was selected for further experiments because it exhibited a higher expression level of lncRNA CCAT2 than the other three cell lines. The cells were divided into 5 groups: i) Control, no treatment; ii) negative control group (si-NC), scramble sequence transfected; iii) lncRNA CCAT2-silenced group (si-CCAT2), transfection with siRNA sequences targeting CCAT2; iv) Wnt pathway inhibitor (FH535) group, $10 \mu \mathrm{M}$ FH535 treatment (cat. no. HY-15721; MedChemExpress); and v) CCAT2 silencing and inhibitor group (si-CCAT2 + FH535), transfection with siRNA sequence targeting CCAT2 and $10 \mu \mathrm{M}$ FH535 treatment. The esophageal cancer Eca-109 cells were digested and passaged with $0.25 \%$ trypsin (Invitrogen; Thermo Fisher Scientific, Inc.). Cells $\left(2 \times 10^{5}\right)$ were inoculated on a 6 -well plate. After $24 \mathrm{~h}$, when the cells reached $30-50 \%$ confluence, $10 \mu 1 / 250 \mu 1$ siRNA was transfected with Lipofectamine ${ }^{\circledR} 2000$ Transfection Reagent (Invitrogen; Thermo Fisher Scientific, Inc.). A further $24 \mathrm{~h}$ later, the medium containing the mixture was preplaced with fresh medium containing $10 \%$ FBS. Cell transfection was assessed by reverse transcription-quantitative PCR (RT-qPCR). The sequences of the control and lncRNA CCAT2 siRNAs were as follows: si-CCAT2 sense strand, 5'-GCCUGUAGGAAG AGUCAAATT-3'; si-CCAT2 antisense strand, 5'-UUUGAC UCUUCCUACAGGCTT-3'; si-NC sense strand, 5'-UUC UCCGAACGUGUCACGUTT-3'; and si-NC antisense strand, 5'-ACGUGACACGUUCGGAGAATT-3'.

$R T$ - $q P C R$. Total RNA was extracted from each cell line using the Total RNA Extraction kit (Invitrogen; Thermo Fisher Scientific, Inc.), and RNA was reverse-transcribed into cDNA using SuperScript III Reverse Transcriptase (Thermo Fisher Scientific, Inc.). SYBR Green PCR kit (Qiagen, Inc.) and Mastercycler ${ }^{\circledR}$ Ep Realplex2 (Eppendorf) were used for RT-qPCR. The RT-qPCR was performed using $2 \mu \mathrm{l}$ cDNA as a template under the following conditions: $95^{\circ} \mathrm{C}$ for $10 \mathrm{~min}$, $95^{\circ} \mathrm{C}$ for $15 \mathrm{sec}$ and $60^{\circ} \mathrm{C}$ for $1 \mathrm{~min}$ for 40 cycles. GAPDH was used as the internal reference and the relative expression of lncRNA CCAT 2 was calculated by the $2^{-\Delta \Delta C q}$ method (20). The following primer pairs were used: CCAT2 forward, 5'-AGA CAGTGCCAGCCAACC-3' and reverse, 5'-TGCCAAACC CTTCCCTTA-3'; and GAPDH forward, 5'-AATGGACAA CTGGTCGTGGAC-3' and reverse, 5'-CCCTCCAGGGGA TCTGTTTG-3'.

MTT assay. Cells ( $100 \mu \mathrm{l} ; 1 \times 10^{4}$ cells $\left./ \mathrm{ml}\right)$ were inoculated on a 96-well flat-bottomed culture plate and cultured for 24, 48, 72 and $96 \mathrm{~h}$. MTT $(100 \mu \mathrm{g})$ was added and incubated at $37^{\circ} \mathrm{C}$ for $4 \mathrm{~h}$. The supernatant was dissolved with $200 \mu \mathrm{l}$ DMSO (Sigma-Aldrich; Merck KGaA). Optical density (OD) of each well was measured at a wavelength of $490 \mathrm{~nm}$ using a plate reader (Bio-Rad Laboratories). The relative absorbance of each group was calculated by the following equation:

$$
\text { Relative absorbance }=\frac{O D_{\text {Experiment }}-O D_{\text {Blank }}}{O D_{\text {control }}-O D_{\text {Blank }}}
$$

Wound-healing assay. Cells $\left(\sim 1.0 \mathrm{ml} ; 3 \times 10^{5}\right.$ cells $\left./ \mathrm{ml}\right)$ were plated in each well (6-well plate). When cells reached $100 \%$ confluence within $24 \mathrm{~h}$, a $10-\mu 1$ pipette tip was used to scratch the monolayer of cells. The cells were washed with PBS twice to remove suspended cells and serum-free medium was gently added. The cell-free wound area was photographed with an inverted microscope (Olympus Corporation) and the results were analyzed by ImageJ $1.46 \mathrm{r}$ software (National Institutes of Health). The percentage of the wound size at $24 \mathrm{~h}$ relative to the $0 \mathrm{~h}$ time point of each treatment group was calculated.

Transwell assay. Matrigel mixture $(\sim 50 \mu \mathrm{l})$ was added to the upper chamber of Transwell inserts (EMD Millipore) and incubated at $37^{\circ} \mathrm{C}$ for $30 \mathrm{~min}$. Cells $\left(2 \times 10^{5}\right.$ cells $\left./ \mathrm{ml}\right)$ were resuspended in serum-free DMEM (Gibco; Thermo Fisher Scientific, Inc.). A total of $\sim 100 \mu \mathrm{l}$ cell suspension was added into the upper compartment of the chamber, and $600 \mu \mathrm{l}$ of $10 \%$ FBS-DMEM culture media was added to the lower chamber. Membranes were collected after $24 \mathrm{~h}$ incubation, fixed in 5\% glutaraldehyde at $4^{\circ} \mathrm{C}$ for $30 \mathrm{~min}$, stained with $0.5 \%$ crystal violet at room temperature for $20 \mathrm{~min}$ and observed under a light microscope (Olympus Corporation) at x200 magnification. Images of nine random fields were captured for analysis of the number of invading cells. 
A

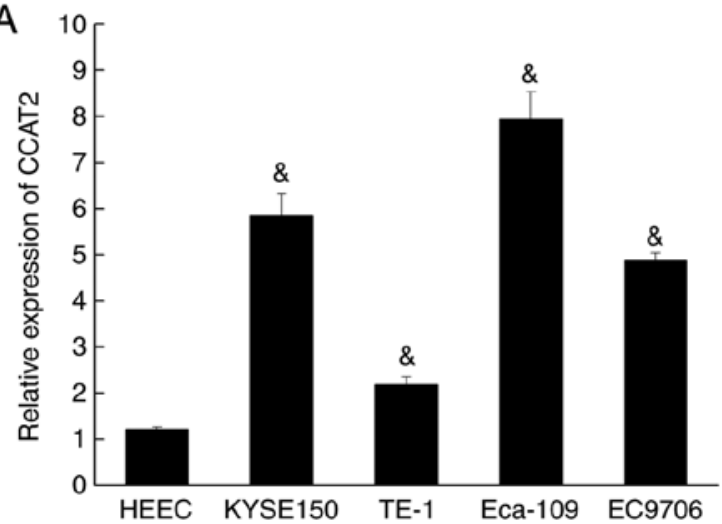

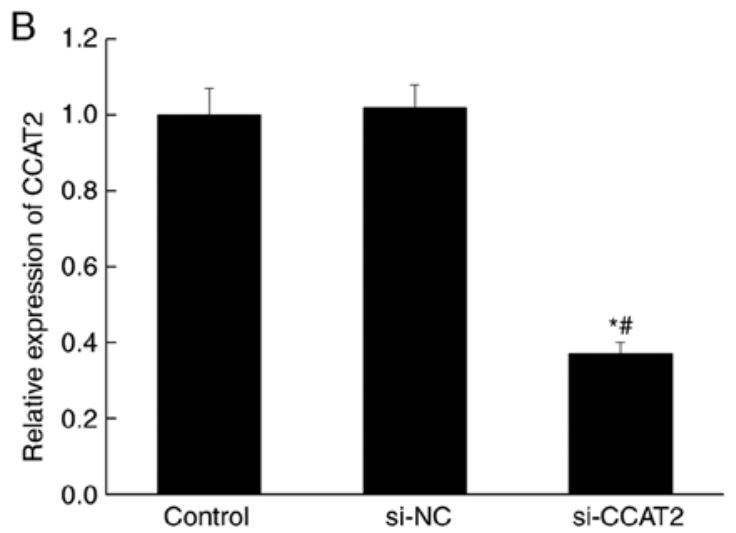

Figure 1. Detection of lncRNA CCAT2 expression by reverse transcription-quantitative PCR. (A) LncRNA CCAT2 expression in esophageal cancer cell lines was high compared with normal HEEC cells. ${ }^{\&} \mathrm{P}<0.05$ vs. HEEC. (B) Expression of 1ncRNA CCAT2 in si-CCAT2 Eca-109 cells, compared with control and si-NC groups. ${ }^{*} \mathrm{P}<0.05$ vs. control; ${ }^{\#} \mathrm{P}<0.05$ vs. si-NC. Lnc, long non-coding; CCAT2, colon cancer-associated transcript 2 ; si-CCAT2, small interfering RNA targeting CCAT2; si-NC, small interfering RNA negative control.

Flow cytometry. Cells were digested by trypsin and collected by centrifugation at $11,180 \mathrm{x}$ g for $5 \mathrm{~min}$ at $4^{\circ} \mathrm{C}$. The cells were washed twice with pre-cooled sterile PBS solution at $4^{\circ} \mathrm{C}$. Cells $\left[\sim 195 \mu 1 ; 1 \times 10^{6}\right.$ cells in $250 \mu 11 \mathrm{X}$ binding buffer (Beyotime Institute of Biotechnology)] were incubated with $5 \mu \mathrm{l}$ of FITC-labeled annexin-V (Beyotime Institute of Biotechnology) for $3 \mathrm{~min}$. Then, $10 \mu \mathrm{l}$ propidium iodide solution $(20 \mu \mathrm{g} / \mathrm{ml})$ was added and incubated in the dark for $10 \mathrm{~min}$ at room temperature. Binding buffer ( $\sim 400 \mu 11 \mathrm{X}$ solution) was added prior to analysis using a flow cytometer (Gallios; Beckman Coulter, Inc.) and Cell Quest 5.1 software (BD Biosciences). The cell numbers at different stages were recorded and the ratio of apoptotic cells was defined as the ratio of cells in quadrants 2 and 4 to total cells.

Immunocytochemistry. Cells, cultured for $24 \mathrm{~h}$, were washed with PBS two to three times and fixed with paraformaldehyde for $30 \mathrm{~min}$. PBS was used to wash the cells two to three times prior to adding $0.5 \%$ Triton $\mathrm{X}-100$ in PBS and incubated for $20 \mathrm{~min}$. This was followed by two to three PBS washes before $3 \% \mathrm{H}_{2} \mathrm{O}_{2}$ was added for 15-20 min. Cells were then washed with PBS two to three times and $5 \%$ bovine serum albumin (Beyotime Institute of Biotechnology) was added and incubated at $37^{\circ} \mathrm{C}$ for $30 \mathrm{~min}$. The primary antibodies, including rabbit anti-human anti- $\beta$-catenin (1:200; cat. no. ab6302) or anti-PCNA (1:100; cat. no. ab15497) (both Abcam), were added and incubated at $37^{\circ} \mathrm{C}$ for $30 \mathrm{~min}$. After two to three PBS washes, horseradish peroxidase-conjugated goat anti-rabbit IgG $(1: 1,000$; cat. no. ABIN101988; antibodies-online GmBH) was added at $37^{\circ} \mathrm{C}$ for $30 \mathrm{~min}$. Cells were washed with PBS two to three times before streptavidin-biotin complex (Beyotime Institute of Biotechnology) was added and incubated at $37^{\circ} \mathrm{C}$ for $30 \mathrm{~min}$. Following three washes with PBS, 3,3'-diaminobenzidine was added, followed by incubation with hematoxylin at room temperature for $2 \mathrm{~min}$ and washing with ethanol at increasing concentrations $(70 \%$ alcohol for $1 \mathrm{~min}, 80 \%$ alcohol for $1 \mathrm{~min}, 95 \%$ alcohol for $2 \mathrm{~min}$ and absolute ethanol for $4 \mathrm{~min}$ ). Observations were performed at x400 magnification under a light microscope (Olympus

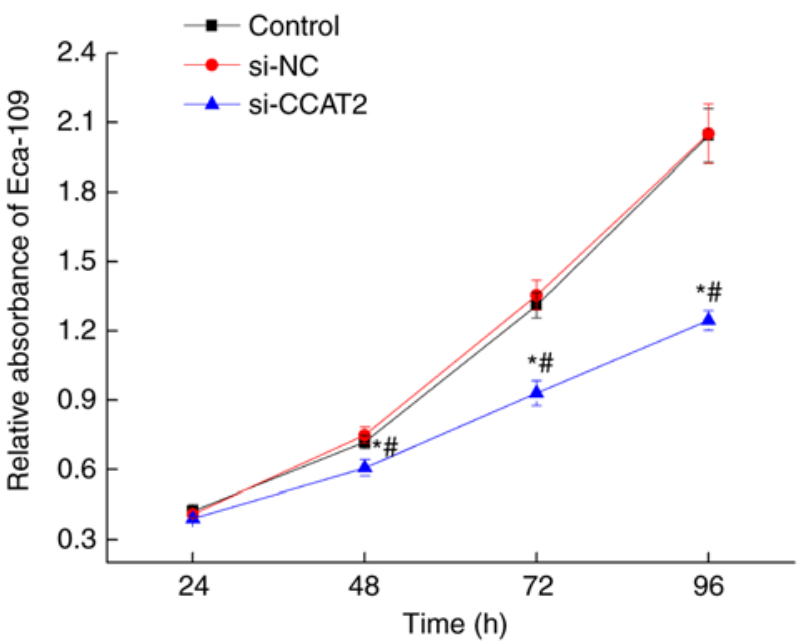

Figure 2. Effect of 1ncRNA CCAT2 knockdown on the proliferation of Eca-109 cells. The proliferation of Eca-109 cells was impaired following lncRNA CCAT2 knockdown with si-CCAT2, compared with the control and si-NC groups. ${ }^{*} \mathrm{P}<0.05$ vs. control; ${ }^{~} \mathrm{P}<0.05$ vs. si-NC. Lnc, long non-coding; CCAT2, colon cancer-associated transcript 2; si-CCAT2, small interfering RNA targeting CCAT2; si-NC, small interfering RNA negative control.

Corporation) and three to five fields of each section were randomly selected for analysis.

Western blotting. Cells were lysed in RIPA buffer (Beyotime Institute of Biotechnology) and the protein concentration was measured by the bicinchoninic acid (Pierce ${ }^{\mathrm{TM}}$ BCA Protein Assay kit; Thermo Fisher Scientific, Inc.). Each protein sample $(\sim 40 \mu \mathrm{g})$ was separated on a SDS-PAGE 10\% gel (Mini-Protean-3 type; Bio-Rad Laboratories) and then transferred to a PVDF membrane (Merck KGaA) for $30 \mathrm{~min}$. The membrane was blocked with $5 \%$ non-fat dry milk in TBST solution for $1 \mathrm{~h}$. TBST with $3 \%$ bovine serum albumin was used to dilute each of the antibodies, including rabbit anti-human anti-Bax (cat. no. ab53154), anti-APC (ab15270, Abcam), anti-cyclin D1 (cat. no. ab226977), anti-c-Myc (cat. no. ab39688) and $\beta$-actin (cat. no. ab8227) (all 1:1,000) polyclonal antibodies, and goat anti-rabbit IgG (1:2,000; cat. no. ab6721) (all Abcam). The membrane 
A

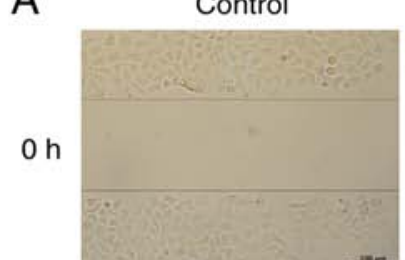

$24 \mathrm{~h}$

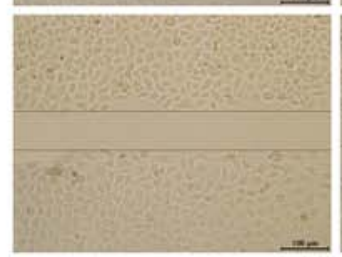

$\mathrm{B}$

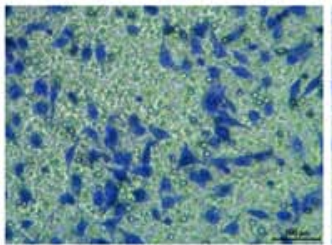

si-NC
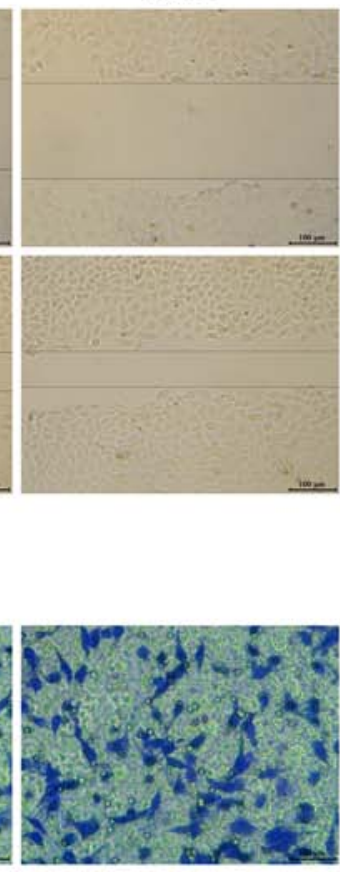

si-CCAT2
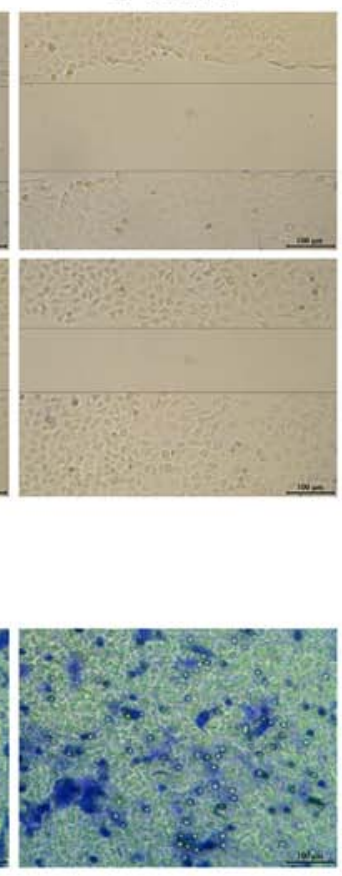
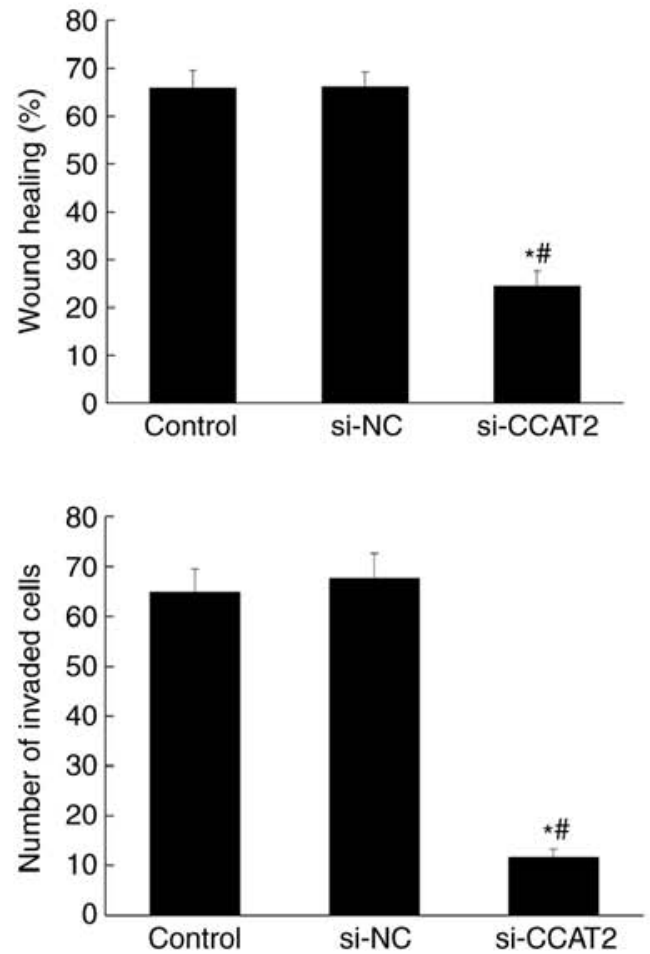

Figure 3. Effect of lncRNA CCAT2 knockdown on the migration and invasion of Eca-109 cells. The migration and invasion of Eca-109 cells, detected by (A) a wound-healing assay and (B) a Transwell invasion assay, were impaired in the si-CCAT2 group, compared with the control and si-NC groups. Magnification, x 200. ${ }^{*} \mathrm{P}<0.05$ vs. control; ${ }^{*} \mathrm{P}<0.05$ vs. si-NC. Lnc, long non-coding; CCAT2, colon cancer-associated transcript 2 ; si-CCAT2, small interfering RNA targeting CCAT2; si-NC, small interfering RNA negative control.

was incubated with primary antibody overnight at $4^{\circ} \mathrm{C}$. Following incubation with horseradish peroxidase-labeled goat anti-rabbit secondary antibody $(1: 1,000$; cat. no. ABIN101988; Antibodies Online) at room temperature for $1 \mathrm{~h}$, the ECL system (Thermo Fisher Scientific, Inc.) was used to detect the signals. The expression levels were quantified by Image J $1.46 \mathrm{r}$ software, and $\beta$-actin was used as an internal control.

Statistical analysis. Each experiment was repeated at least three times. SPSS 19.0 (IBM Corp.) was used to analyze all the data, which are expressed as the mean \pm SD. One-way analysis of variance was used for analysis of data among groups. Least-Significant Difference was used for post hoc analysis. $\mathrm{P}<0.05$ was considered to indicate s statistically significant difference.

\section{Results}

Expression of lncRNA CCAT2 is higher in esophageal cancer cell lines. The expression of IncRNA CCAT2 in four esophageal cancer cell lines (Eca-109, EC9706, KYSE150 and TE-1) and one normal esophageal epithelial cell (HEEC) was examined by RT-qPCR. The expression was significantly higher in all esophageal cancer cell lines compared with that in HEEC ( $\mathrm{P}<0.05$; Fig. 1A). Subsequently, siRNA was used to silence lncRNA CCAT2 in Eca-109 cells. The RT-qPCR data showed no off-target effect occurring, and the knockdown of lncRNA CCAT2 was successfully performed (Fig. 1B).
Inhibition of IncRNA CCAT2 attenuates proliferation, migration and invasion of esophageal cancer cells. After $24,48,72$, and $96 \mathrm{~h}$ of culture following transfection with si-CCAT2, proliferation decreased significantly in the si-CCAT2 group compared with the control and si-NC groups $(\mathrm{P}<0.05$; Fig. 2). To further investigate the effect of lncRNA CCAT2 on the metastasis of esophageal cancer cells, the wound-healing and Transwell assays were performed. As shown in Fig. 3, the cell migration and invasion in the si-CCAT2 group were significantly suppressed compared with the control and si-NC groups $(\mathrm{P}<0.05)$.

Inhibition of IncRNA CCAT2 promotes apoptosis in esophageal cancer cells. Flow cytometry was used to analyze apoptosis in esophageal cancer cells, following annexin $\mathrm{V}$ staining. The number of apoptotic cells in the si-CCAT2 group was significantly higher compared with the control and si-NC groups $(\mathrm{P}<0.05$; Fig. 4). Similarly, the immunohistochemistry staining showed significantly decreased expression of $\beta$-catenin and PCNA in the si-CCAT2 group ( $\mathrm{P}<0.05$; Fig. 5). Protein expression, determined by western blotting, showed significant upregulation of Bax and APC in the si-CCAT2 group compared with the control and si-NC groups, whereas cyclin D1 and c-Myc proteins were significantly downregulated $(\mathrm{P}<0.05$; Fig. 6).

LncRNA CCAT2 and Wnt signaling pathway. To further analyze how IncRNA CCAT2 functions in esophageal cancer cells, the effect of the Wnt signaling pathway 
A

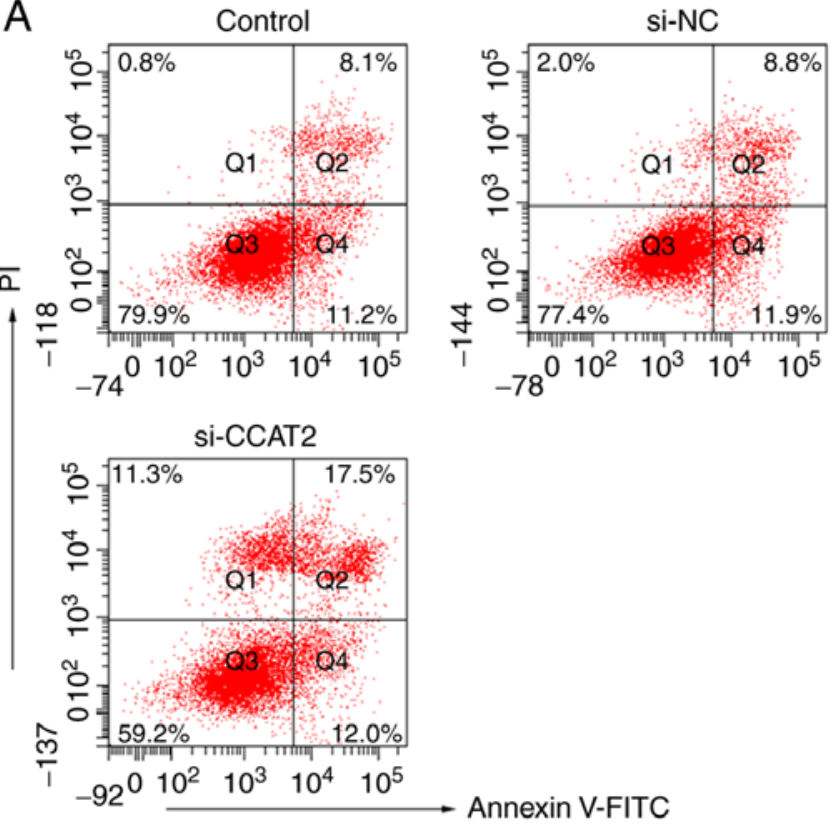

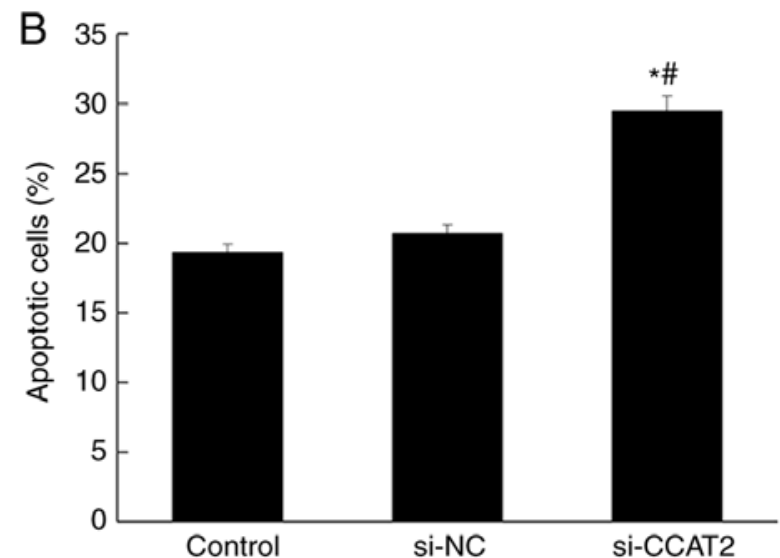

Control

si-NC

si-CCAT2

Figure 4. Effect of lncRNA CCAT2 knockdown on the apoptosis of Eca-109 cells. (A) Apoptosis analysis by flow cytometry and (B) quantification of apoptotic cells. The percentage of apoptotic cells was higher in the si-CCAT2 group, compared with the control and si-NC groups. ${ }^{*} \mathrm{P}<0.05$ vs. control; ${ }^{*} \mathrm{P}<0.05$ vs. si-NC. Lnc, long non-coding; CCAT2, colon cancer-associated transcript 2; si-CCAT2, small interfering RNA targeting CCAT2; si-NC, small interfering RNA negative control.
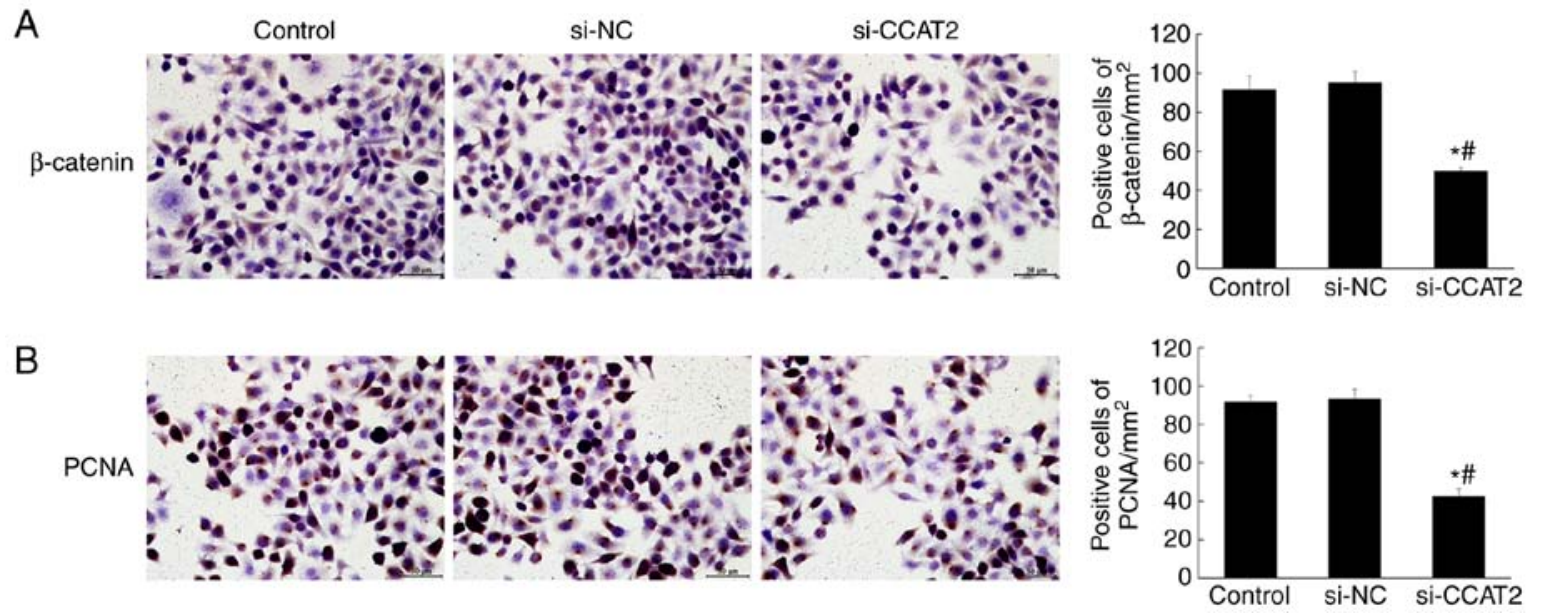

Figure 5. Immunohistochemical detection of $\beta$-catenin and PCNA protein expression. Staining and positive cell counts of (A) $\beta$-catenin and (B) PCNA. Magnification, $\mathrm{x} 400$. Positive cell counts were lower in the si-CCAT2 group, compared with the control and si-NC groups. ${ }^{*} \mathrm{P}<0.05$ vs. control; ${ }^{*} \mathrm{P}<0.05$ vs. si-NC. PCNA, proliferating cell nuclear antigen; CCAT2, colon cancer-associated transcript 2; si-CCAT2, small interfering RNA targeting CCAT2; si-NC, small interfering RNA negative control.

on the cell proliferation, invasion and metastasis was investigated, using a Wnt signaling inhibitor (FH535). No differences in the effects on apoptosis, proliferation, migration and invasion of Eca-109 cells were observed between the si-CCAT2 + FH535 group and the si-CCAT2 or FH535 groups (Figs. 7-9). Expression of $\beta$-catenin, PCNA, Bax, APC, cyclin D1 and c-Myc were also similar among these groups (Figs. 10 and 11).

\section{Discussion}

$\beta$-catenin can bind T-cell factor (TCF) family DNA-binding proteins and translocate to the nucleus. This complex regulates cellular differentiation and proliferation (21-24). Wnt signaling molecules can activate the $\beta$-catenin/TCF complex and induce gene expression (21-23). This signaling pathway has been identified to serve a major role in in certain cancer types including highly malignant carcinoma such as esophageal cancer $(21,25-27)$. It is believed that this pathway plays a critical role in the maintenance and self-renewal of cancer stem cells, which leads to malignant tumors and poor prognosis $(22,25)$. Wnt signaling is positively correlated with higher ratio of cancer stem cells and advanced clinical stages of esophageal carcinoma (25). Other genes, such as Dapper homolog 2, naked cuticle homolog 2, microRNA (miR)-942, transcription factor Sox17 and miR-141, can modulate the 

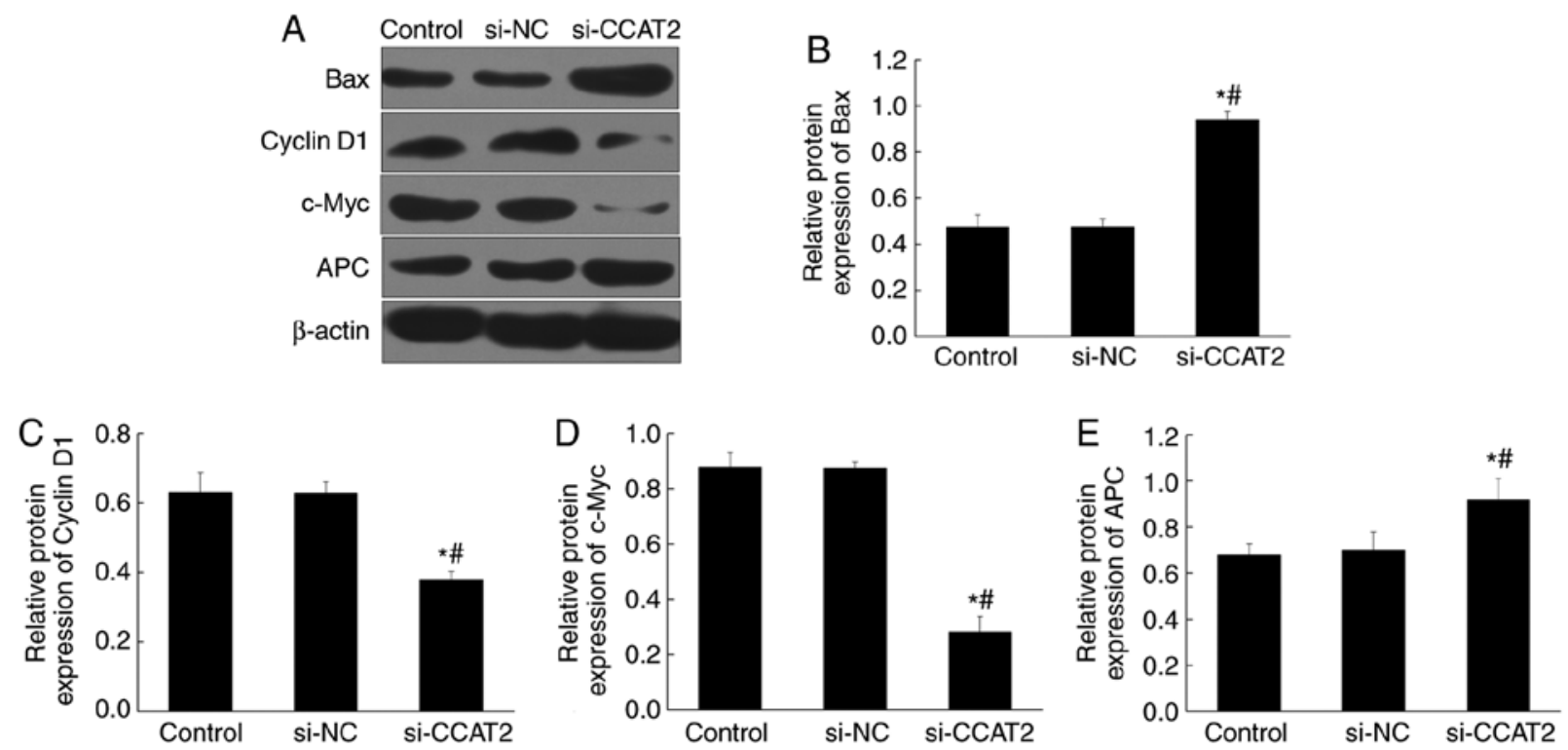

Figure 6. Expression levels of pro-apoptotic and Wnt target proteins in Eca-109. (A) The expression of Bax, cyclin D1, c-Myc and APC by western blotting. The relative protein expression of (B) Bax, (C) cyclin D1, (D) c-Myc and (E) APC in the si-CCAT2 group compared with the control and si-NC groups. ${ }^{*} \mathrm{P}<0.05$ vs. control; " $\mathrm{P}<0.05$ vs. si-NC. APC, adenomatous polyposis coli; CCAT2, colon cancer-associated transcript 2; si-CCAT2, small interfering RNA targeting CCAT2; si-NC, small interfering RNA negative control.

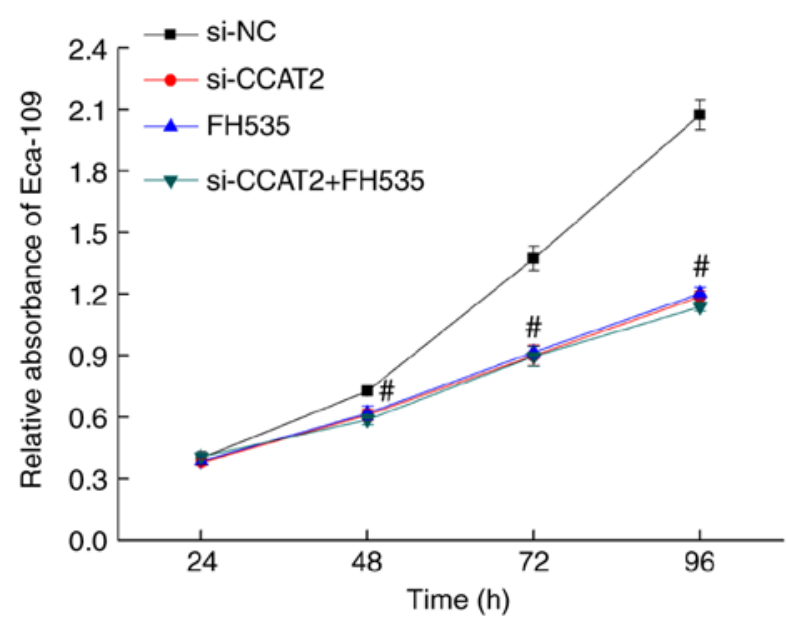

Figure 7. Effect of the Wnt pathway inhibitor (FH535) on the proliferation of Eca-109 cells. Proliferation was equally suppressed in the si-CCAT2, FH535 and si-CCAT2 + FH535 groups, compared with the si-NC group. ${ }^{~} \mathrm{P}<0.05$ vs. si-NC. CCAT2, colon cancer-associated transcript 2; si-CCAT2, small interfering RNA targeting CCAT2; si-NC, small interfering RNA negative control.

Wnt signaling pathway and affect tumorigenesis in esophageal cells $(22,23,26,28)$. Human papillomavirus can lead to esophageal cancer via the miR-125b and $\mathrm{Wnt} / \beta$-catenin signaling pathway (27).

Therefore, the inhibition of the Wnt/ $/$-catenin pathway can serve as a potential therapeutic approach for cancer (29-31). FH535 is an inhibitor of $\beta$-catenin, which inhibits cyclin D1 and survivin and decreases the proliferation of human colorectal cancer cells, liver cancer stem cells, hepatocellular carcinoma cells and HepG2 cells (24,32-34). FH535 enhances imatinib-induced apoptosis, decreases $\mathrm{S}$ phase cells, arrests the cell cycle and suppresses the proliferation of cancer cells by targeting the Wnt signaling pathway $(30,32-34)$.
The present study demonstrated that esophageal cancer cell lines had higher expression levels of IncRNA CCAT2 compared with normal esophageal cells. To further explore the function of lncRNA CCAT2, si-CCAT2 was constructed and tested in esophageal cancer Eca-109 cells. The results showed that si-CCAT2 decreased the cell proliferation. Furthermore, the population of apoptotic cells, quantified by annexin $\mathrm{V}$ staining, increased significantly following knockdown of lncRNA CCAT2. This downregulation also significantly decreased cell migration and invasion. To elucidate the molecular mechanism of IncRNA CCAT2, a Wnt inhibitor (FH535) was used to study the associated signaling pathway. FH535 and lncRNA CCAT2 equally elicited suppressive effects on proliferation, migration and invasion, suggesting that lncRNA may function via the Wnt pathway.

LncRNA CCAT2 has been demonstrated to be involved in the Wnt pathway in a number of cancer types, and one of its functions is to modulate the Wnt pathway (35-38). For example, downregulating CCAT2 suppresses the transcriptional activity of Wnt/ $\beta$-catenin signaling pathway and the combination of siCCAT2 and FH535 synergistically inhibits Wnt signaling in breast cancer (39). The present study demonstrates an association between IncRNA CCAT2 and Wnt signaling pathway in esophageal cancer.

In the present study, only one esophageal cancer cell line (Eca-109) was used to study the effects and mechanism of IncRNA CCAT2. Therefore, a limitation in the present findings is that they may not apply to other esophageal cancer cell lines or different esophageal cancer types. In addition, the present results showed that the expression level of IncRNA CCAT2 was different in the four esophageal cancer cell lines, which was not investigated any further in this study. Furthermore, more detailed studies of the regulatory effect of CCAT2 on the Wnt pathway should be conducted. 
A

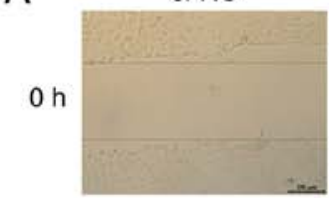

$24 \mathrm{~h}$

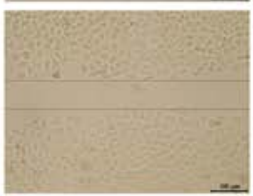

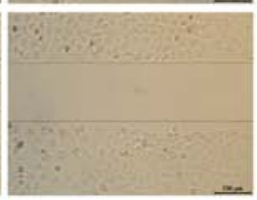

B

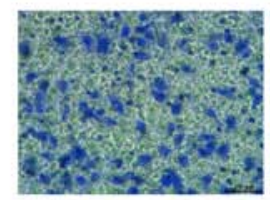

Si-CCAT2
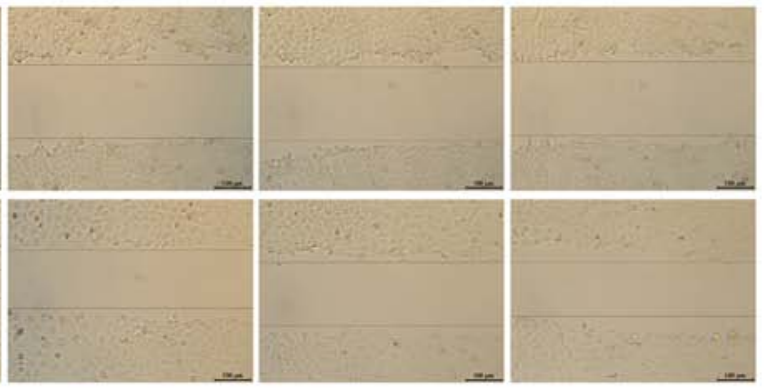

$\mathrm{FH} 535$
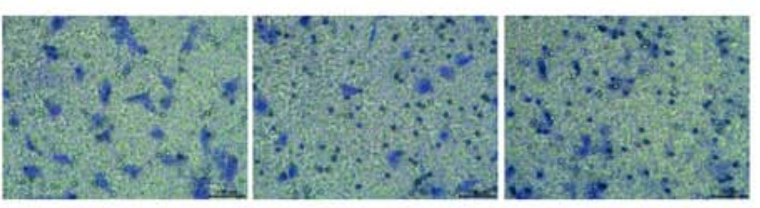
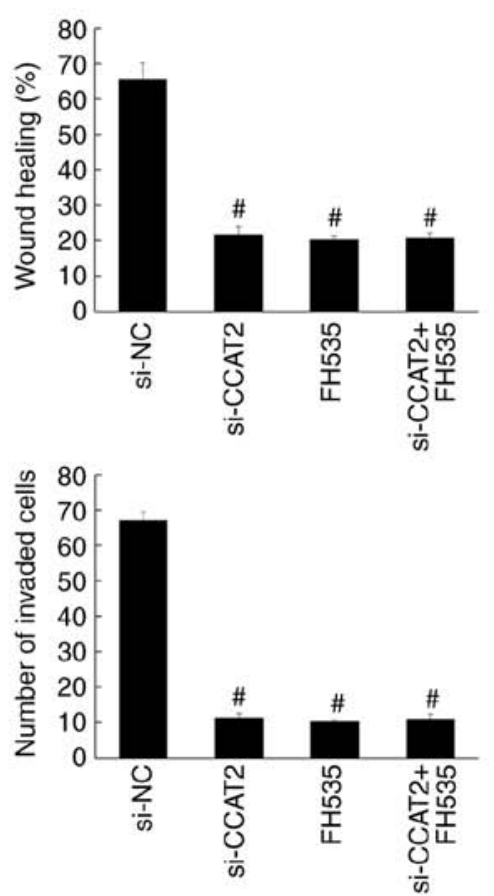

Figure 8. Effect of the Wnt pathway inhibitor (FH535) on the migration and invasion of esophageal cancer cells. (A) Images of the wound-healing assay and the quantification of the rate of wound healing. (B) Images of the Transwell assay and the number of invasive cells. Migration and invasion were decreased in the si-CCAT2, FH535 and si-CCAT2 + FH535 groups, compared with the si-NC group. Magnification, x200. "P<0.05 vs. si-NC. CCAT2, colon cancer-associated transcript 2; si-CCAT2, small interfering RNA targeting CCAT2; si-NC, small interfering RNA negative control.
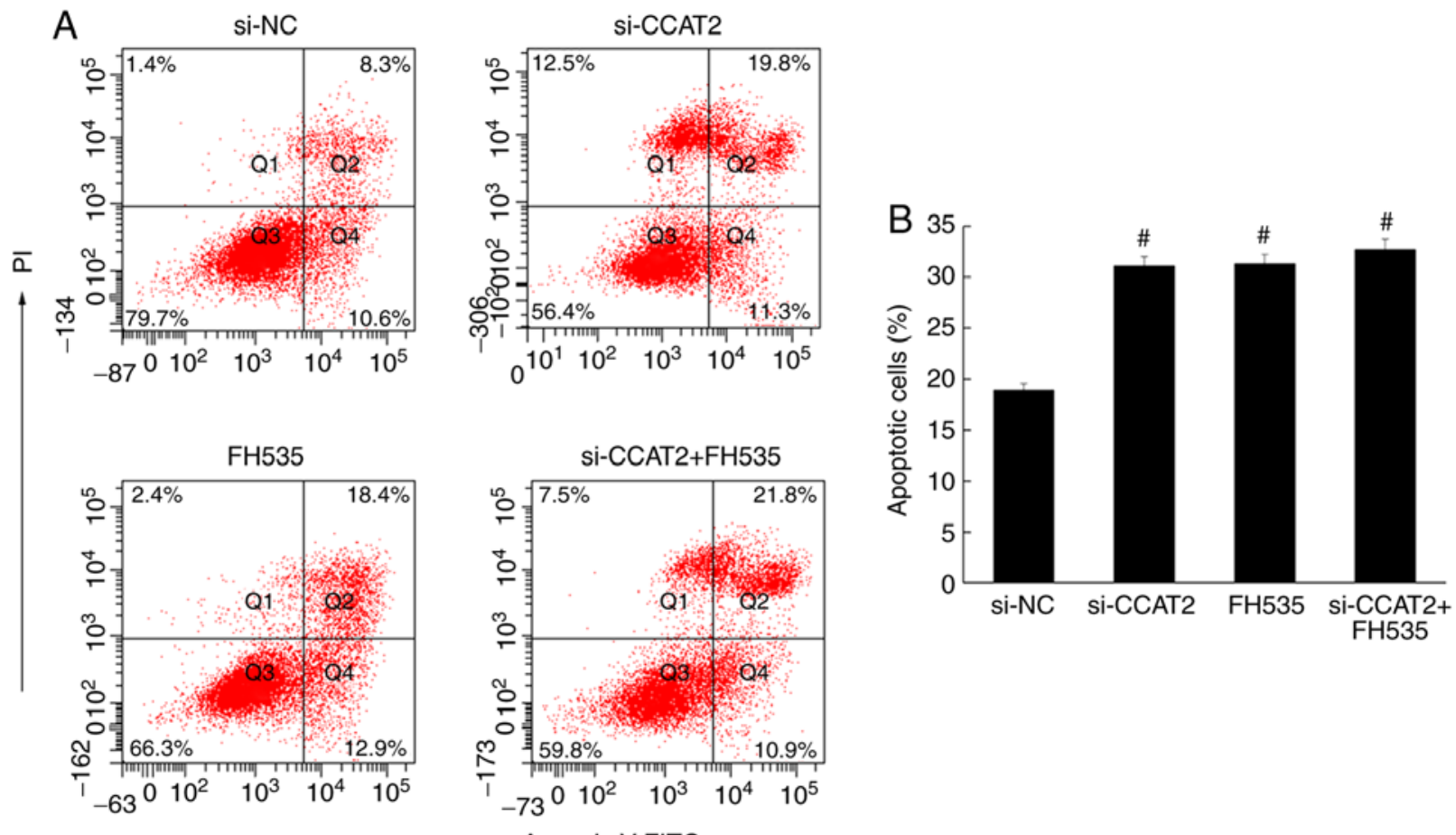

\section{Annexin V-FITC}

Figure 9. Effect of the Wnt pathway inhibitor (FH535) treatment on apoptosis in esophageal cancer cells. (A) Apoptosis analysis by annexin V staining and flow cytometry. (B) Quantification of apoptotic cells demonstrated a larger population in the si-CCAT2, FH535 and si-CCAT2 + FH535 groups, compared with the si-NC group. ${ }^{~} \mathrm{P}<0.05$ vs. si-NC. CCAT2, colon cancer-associated transcript 2; si-CCAT2, small interfering RNA targeting CCAT2; si-NC, small interfering RNA negative control.

In the future, the correlation between the expression level of 1 ncRNA CCAT2 and the proliferation and metastasis of the four esophageal cancer cell lines will be explored. In addition, the hypothesis tested in the present study will be applied in an 

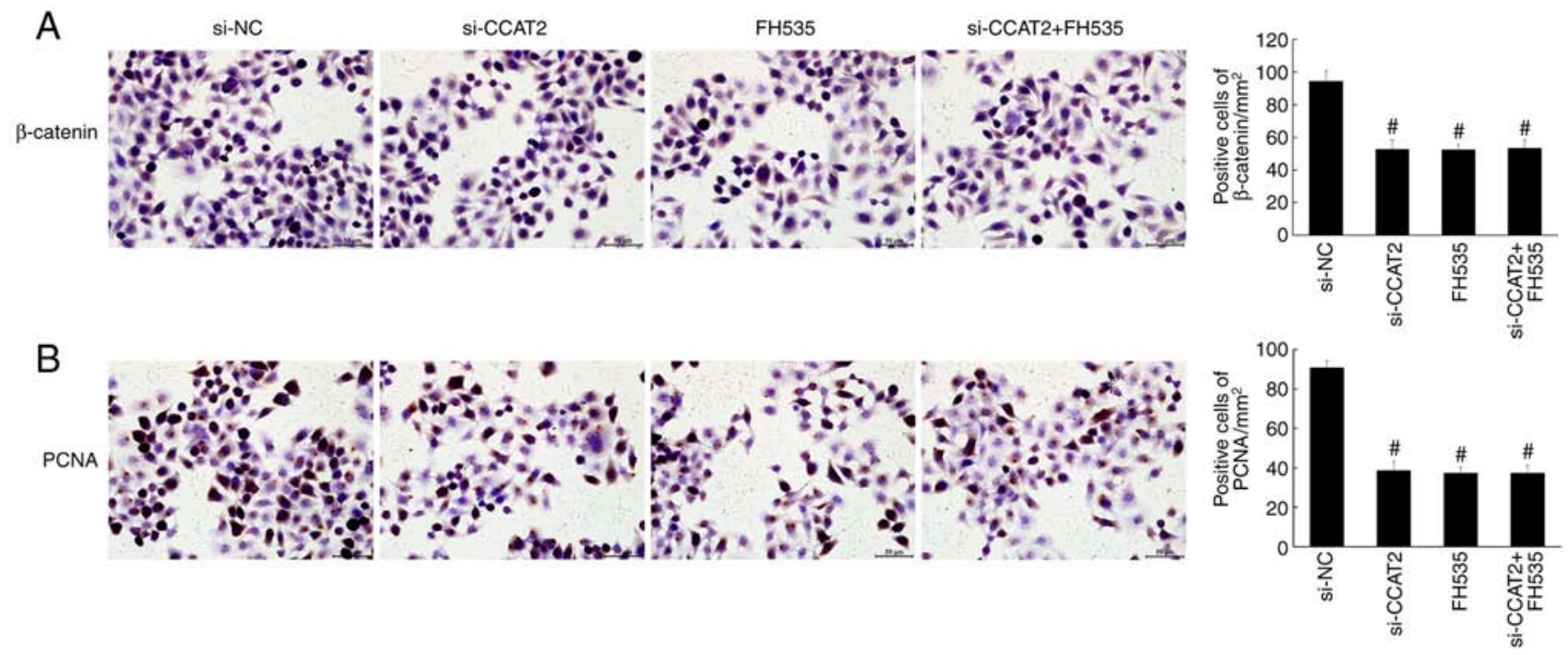

Figure 10. Immunohistochemical detection of the expression levels of $\beta$-catenin and PCNA protein. Expression and positive cell counts of (A) $\beta$-catenin and (B) PCNA were lower in the si-CCAT2, FH535 and si-CCAT2 + FH535 groups, compared with the si-NC) group. Magnification, $\mathrm{x} 400$. ${ }^{\# P} \mathrm{P}<0.05$ vs. si-NC. PCNA, proliferating cell nuclear antigen; CCAT2, colon cancer-associated transcript 2; si-CCAT2, small interfering RNA targeting CCAT2; si-NC, small interfering RNA negative control.
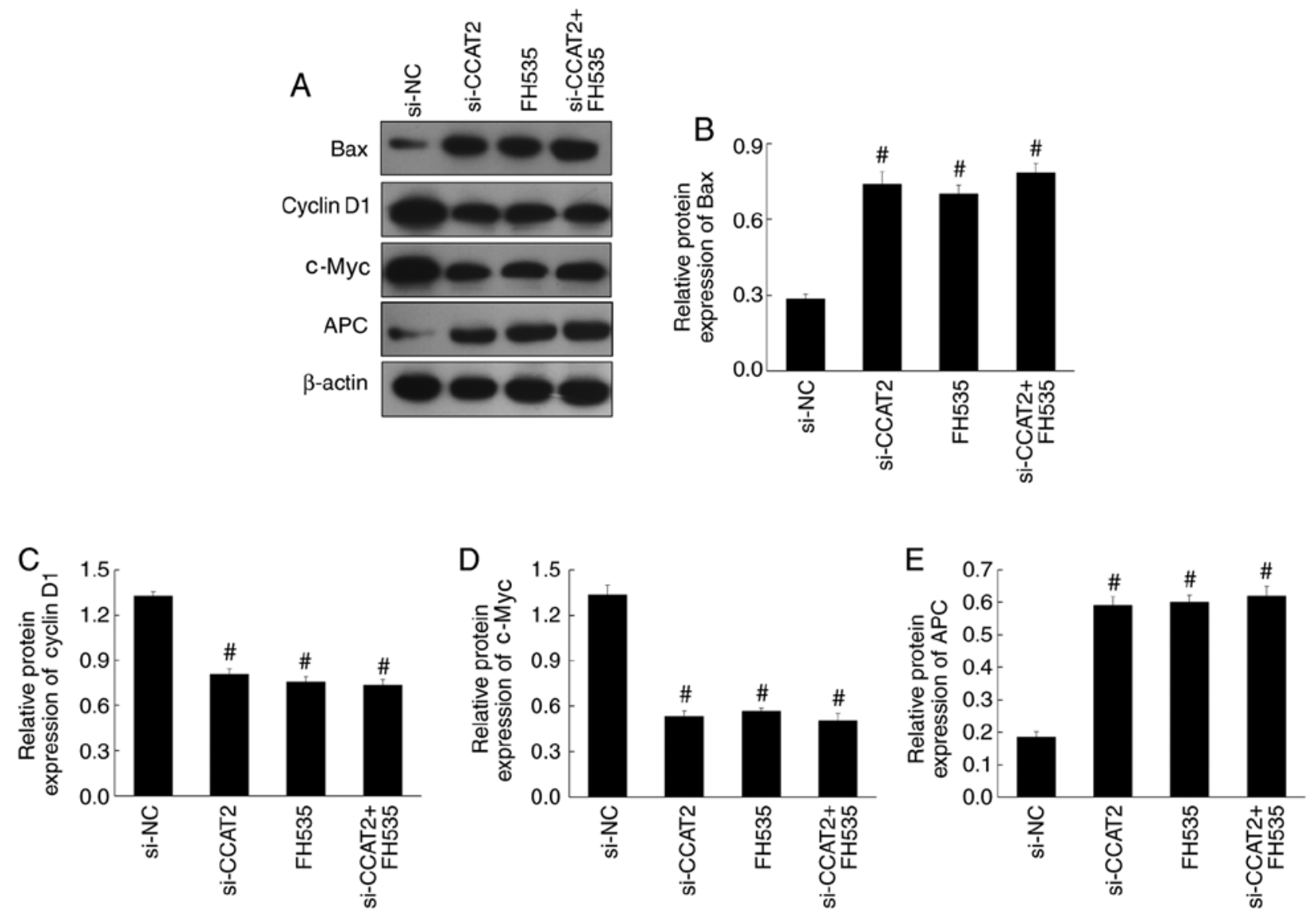

Figure 11. Effect of the Wnt pathway inhibitor (FH535) on the expression levels of pro-apoptotic and Wnt target proteins in Eca-109 cells. (A) The expression of Bax, cyclin D1, c-Myc and APC by western blotting. The relative protein expression of (B) Bax, (C) cyclin D1, (D) c-Myc and (E) APC in the si-CCAT2, FH535 and si-CCAT2 + FH535 groups, compared with the si-NC group. ${ }^{~} \mathrm{P}<0.05$ vs. si-NC. APC, adenomatous polyposis coli; CCAT2, colon cancer-associated transcript 2; si-CCAT2, small interfering RNA targeting CCAT2; si-NC, small interfering RNA negative control.

in vivo model. These studies will provide more critical insights into the mechanism, for the development of novel treatments for esophageal cancer in the future.
In summary, the present study demonstrated that lncRNA CCAT2 was highly expressed in esophageal cancer cells, and its downregulation led to the inhibition of cell proliferation, 
migration and invasion via the Wnt signaling pathway. The results of the present study may provide a theoretical basis for the development of new treatment options for esophageal cancer.

\section{Acknowledgements}

Not applicable.

\section{Funding}

No funding was received.

\section{Availability of data and materials}

The datasets used and/or analyzed during the current study are available from the corresponding author on reasonable request.

\section{Authors' contributions}

XiW and XuW conducted all the experiments, analyzed all the data and wrote the manuscript.

\section{Ethics approval and consent to participate}

Not applicable.

\section{Patient consent for publication}

Not applicable.

\section{Competing interests}

The authors declare that they have no competing interests.

\section{References}

1. Bajpai M, Das KM, Lefferts J, Lisovsky M, Mashimo H, Phillips WA, Srivastava A and To H: Molecular epidemiology of and genetic susceptibility to esophageal cancer. Ann N Y Acad Sci 1325: 40-48, 2014.

2. Napier KJ, Scheerer M and Misra S: Esophageal cancer: A Review of epidemiology, pathogenesis, staging workup and treatment modalities. World J Gastrointest Oncol 6: 112-120, 2014

3. Lin Y, Totsuka Y, He Y, Kikuchi S, Qiao Y, Ueda J, Wei W, Inoue $\mathrm{M}$ and Tanaka $\mathrm{H}$ : Epidemiology of esophageal cancer in Japan and China. J Epidemiol 23: 233-242, 2013

4. Wang J, Qiu M, Xu Y, Li M, Dong G, Mao Q, Yin R and Xu L: Long noncoding RNA CCAT2 correlates with smoking in esophageal squamous cell carcinoma. Tumour Biol 36: 5523-5528, 2015.

5. Łaźniak S, Lutkowska A, Wareńczak-Florczak Ż, Sowińska A, Tsibulski A, Roszak A, Sajdak S and Jagodziński PP: The association of CCAT2 rs6983267 SNP with MYC expression and progression of uterine cervical cancer in the Polish population. Arch Gynecol Obstet 297: 1285-1292, 2018.

6. Jing X, Liang H, Cui X, Han C, Hao C and Huo K: Long noncoding RNA CCAT2 can predict metastasis and a poor prognosis: A meta-analysis. Clin Chim Acta 468: 159-165, 2017.

7. Kasagi $Y$, Oki E, Ando K, Ito S, Iguchi T, Sugiyama M, Nakashima Y, Ohgaki K, Saeki H, Mimori K and Maehara Y: The expression of CCAT2, a novel long noncoding RNA transcript, and rs6983267 single-nucleotide polymorphism genotypes in colorectal cancers. Oncology 92: 48-54, 2017.

8. Lang HL, Hu GW, Zhang B, Kuang W, Chen Y, Wu L and $\mathrm{Xu}$ GH: Glioma cells enhance angiogenesis and inhibit endothelial cell apoptosis through the release of exosomes that contain long non-coding RNA CCAT2. Oncol Rep 38: 785-798, 2017.
9. Ozawa T, Matsuyama T, Toiyama Y, Takahashi N, Ishikawa T, Uetake H, Yamada Y, Kusunoki M, Calin G and Goel A: CCAT1 and CCAT2 long noncoding RNAs, located within the 8q.24.21 'gene desert', serve as important prognostic biomarkers in colorectal cancer. Ann Oncol 28: 1882-1888, 2017.

10. Redis RS, Sieuwerts AM, Look MP, Tudoran O, Ivan C, Spizzo R, Zhang X, de Weerd V, Shimizu M, Ling H, et al: CCAT2, a novel long non-coding RNA in breast cancer: Expression study and clinical correlations. Oncotarget 4: 1748-1762, 2013.

11. Wang YJ, Liu JZ, Lv P, Dang Y, Gao JY and Wang Y: Long non-coding RNA CCAT2 promotes gastric cancer proliferation and invasion by regulating the E-cadherin and LATS2. Am J Cancer Res 6: 2651-2660, 2016

12. Zheng J, Zhao S, He X, Zheng Z, Bai W, Duan Y, Cheng S, Wang J, Liu X and Zhang G: The up-regulation of long non-coding RNA CCAT2 indicates a poor prognosis for prostate cancer and promotes metastasis by affecting epithelial-mesenchymal transition. Biochem Biophys Res Commun 480: 508-514, 2016.

13. Ma Y, Hu X, Shang C, Zhong M and Guo Y: Silencing of long non-coding RNA CCAT2 depressed malignancy of oral squamous cell carcinoma via Wnt/ $\beta$-catenin pathway. Tumour Biol 39: 1010428317717670, 2017.

14. Qiu M, Xu Y, Yang X, Wang J, Hu J, Xu L and Yin R: CCAT2 is a lung adenocarcinoma-specific long non-coding RNA and promotes invasion of non-small cell lung cancer. Tumour Biol 35: 5375-5380, 2014

15. Cai Y, He J and Zhang D: Suppression of long non-coding RNA CCAT2 improves tamoxifen-resistant breast cancer cells response to tamoxifen. Mol Biol (Mosk) 50: 821-827, 2016 (In Russian).

16. Deng X, Zhao Y, Wu X and Song G: Upregulation of CCAT2 promotes cell proliferation by repressing the $\mathrm{P} 15$ in breast cancer. Biomed Pharmacother 91: 1160-1166, 2017.

17. Fan YH, Fang H, Ji CX, Xie H, Xiao B and Zhu XG: Long noncoding RNA CCAT2 can predict metastasis and poor prognosis: A meta-analysis. Clin Chim Acta 466: 120-126, 2017.

18. Redis RS, Vela LE, Lu W, Ferreira de Oliveira J, Ivan C, Rodriguez-Aguayo C, Adamoski D, Pasculli B, Taguchi A, Chen Y, et al: Allele-specific reprogramming of cancer metabolism by the long non-coding RNA CCAT2. Mol Cell 61: 520-534, 2016.

19. Zhang X, Xu Y, He C, Guo X, Zhang J, He C, Zhang L, Kong M, Chen B and Zhu C: Elevated expression of CCAT2 is associated with poor prognosis in esophageal squamous cell carcinoma. J Surg Oncol 111: 834-839, 2015.

20. Livak KJ and Schmittgen TD: Analysis of relative gene expression data using real-time quantitative PCR and the 2(-Delta Delta C(T)) method. Methods 25: 402-408, 2001

21. Mizushima T, Nakagawa H, Kamberov YG, Wilder EL, Klein PS and Rustgi AK: Wnt-1 but not epidermal growth factor induces beta-catenin/T-cell factor-dependent transcription in esophageal cancer cells. Cancer Res 62: 277-282, 2002.

22. Ge C, Wu S, Wang W, Liu Z, Zhang J, Wang Z, Li R, Zhang Z, Li Z, Dong S, et al: miR-942 promotes cancer stem cell-like traits in esophageal squamous cell carcinoma through activation of Wnt/ $\beta$-catenin signalling pathway. Oncotarget 6: 10964-10977, 2015.

23. Jia Y, Yang Y, Zhan Q, Brock MV, Zheng X, Yu Y, Herman JG and Guo M: Inhibition of SOX17 by microRNA 141 and methylation activates the WNT signaling pathway in esophageal cancer. J Mol Diagn 14: 577-585, 2012.

24. Shi M, Cheng J, He Y, Jiang Z, Bodinga BM, Liu B, Chen H and Li Q: Effect of FH535 on in vitro maturation of porcine oocytes by inhibiting WNT signaling pathway. Anim Sci J 89: 631-639, 2018.

25. Pang Y, Liu J, Li X, Zhang Y, Zhang B, Zhang J, Du N, Xu C, Liang R, Ren H, et al: Nano Let7b sensitization of eliminating esophageal cancer stemlike cells is dependent on blockade of Wnt activation of symmetric division. Int J Oncol 51: 1077-1088, 2017.

26. Cao B, Yang W, Jin Y, Zhang M, He T, Zhan Q, Herman JG, Zhong $\mathrm{G}$ and Guo M: Silencing NKD2 by promoter region hypermethylation promotes esophageal cancer progression by activating Wnt signaling. J Thorac Oncol 11: 1912-1926, 2016.

27. Zang B, Huang G, Wang X and Zheng S: HPV-16 E6 promotes cell growth of esophageal cancer via downregulation of miR-125b and activation of Wnt/ $\beta$-catenin signaling pathway. Int J Clin Exp Pathol 8: 13687-13694, 2015.

28. Zhang M, Linghu E, Zhan Q, He T, Cao B, Brock MV, Herman JG, Xiang R and Guo M: Methylation of DACT2 accelerates esophageal cancer development by activating Wnt signaling. Oncotarget 7: 17957-17969, 2016 
29. Gustafson CT,MamoT, Shogren KL,Maran A and Yaszemski MJ FH535 suppresses osteosarcoma growth in vitro and inhibits Wnt signaling through tankyrases. Front Pharmacol 8: 285, 2017.

30. Suknuntha K, Thita T, Togarrati PP, Ratanachamnong P, Wongtrakoongate P, Srihirun S, Slukvin I and Hongeng S: Wnt signaling inhibitor FH535 selectively inhibits cell proliferation and potentiates imatinib-induced apoptosis in myeloid leukemia cell lines. Int J Hematol 105: 196-205, 2017.

31. Wen D, Liao T, Ma B, Qu N, Shi RL, Lu ZW, Wang YL, Wei WJ and Ji QH: Downregulation of CSN6 attenuates papillary thyroid carcinoma progression by reducing $\mathrm{Wnt} / \beta$-catenin signaling and sensitizes cancer cells to FH535 therapy. Cancer Med 7: 285-296, 2018.

32. Liu J, Li G, Liu D and Liu J: FH535 inhibits the proliferation of HepG 2 cells via downregulation of the $\mathrm{Wnt} / \beta$-catenin signaling pathway. Mol Med Rep 9: 1289-1292, 2014.

33. Gedaly R, Galuppo R, Daily MF, Shah M, Maynard E, Chen C, Zhang X, Esser KA, Cohen DA, Evers BM, et al: Targeting the $\mathrm{Wnt} / \beta$-catenin signaling pathway in liver cancer stem cells and hepatocellular carcinoma cell lines with FH535. PLoS One 9: e99272, 2014.

34. Chen Y, Rao X, Huang K, Jiang X, Wang H and Teng L: FH535 inhibits proliferation and motility of colon cancer cells by targeting Wnt $/ \beta$-catenin signaling pathway. J Cancer 8: 3142-3153, 2017.

35. Guo H, Hu G, Yang Q, Zhang P, Kuang W, Zhu X and Wu L: Knockdown of long non-coding RNA CCAT2 suppressed proliferation and migration of glioma cells. Oncotarget 7: 81806-81814, 2016.
36. Huang JL, Liao Y, Qiu MX, Li J and An Y: Long non-coding RNA CCAT2 promotes cell proliferation and invasion through regulating Wnt/ $\beta$-catenin signaling pathway in clear cell renal cell carcinoma. Tumour Biol 39: 1010428317711314, 2017.

37. Sarrafzadeh S, Geranpayeh L, Tasharrofi B, Soudyab M, Nikpayam E, Iranpour M, Mirfakhraie R, Gharesouran J, Ghafouri-Fard S and Ghafouri-Fard S: Expression study and clinical correlations of MYC and CCAT2 in breast cancer patients. Iran Biomed J 21: 303-311, 2017.

38. Wang B, Liu M, Zhuang R, Jiang J, Gao J, Wang H, Chen $\mathrm{H}$, Zhang Z, Kuang Y and Li P: Long non-coding RNA CCAT2 promotes epithelial-mesenchymal transition involving Wnt/ $\beta$-catenin pathway in epithelial ovarian carcinoma cells. Oncol Lett 15: 3369-3375, 2018.

39. Cai Y, He J and Zhang D: Long noncoding RNA CCAT2 promotes breast tumor growth by regulating the Wnt signaling pathway. Onco Targets Ther 8: 2657-2664, 2015. Attribution-NonCommercial-NoDerivatives 4.0 International (CC BY-NC-ND 4.0) License. 